\title{
Pattern of open eye injuries in northwest Turkey: a retrospective study
}

\author{
Türkiye'nin kuzeybatısındaki açık göz yaralanma paterni: \\ Retrospektif bir çalışma
}

\author{
Levent ALTINTAŞ, ${ }^{1}$ Özgül ALTINTAŞ, ${ }^{2}$ Nurşen YÜKSEL,${ }^{2}$ \\ Dilara PIRHAN, ${ }^{2}$ Berna ÖZKAN, ${ }^{2}$ Yusuf ÇAĞLAR ${ }^{2}$
}

\section{BACKGROUND}

We aimed to review the epidemiology and visual outcome of patients with open globe injuries in the northwest part of Turkey.

\section{METHODS}

All patients admitted to the Department of Ophthalmology, Kocaeli University Faculty of Medicine with open globe injuries between 2004-2008 were reviewed retrospectively.

\section{RESULTS}

Ninety-five eyes of 95 patients, aged between 3 and 79 years, were reviewed. The type of open eye injury was laceration in 76 eyes (80\%) and rupture in 19 eyes (20\%). In all age groups, projectile objects were the most common cause of injury. In patients 18 years and older, sharp objects $(11.1 \%)$ were the least prevalent cause of open globe injuries; however, traumas with sharp objects were common in patients younger than 18 years $(38.1 \%)(\mathrm{p}=0.01)$. In patients younger than 18 years, most injuries occurred at home $(68.3 \%)$, while in patients 18 years and older, the majority of ocular traumas occurred at work $(59.2 \%)$ $(\mathrm{p}=0.000)$. Isolated Zone I lesions showed more improvement in visual acuity than other zones $(p=0.043)$.

\section{CONCLUSION}

Open globe injury in northwest Turkey varied with age and gender. Education and safety precautions are essential to prevent open eye injuries.

Key Words: Open eye injury; prognosis; Turkey.

\section{$\boldsymbol{A M A C ̧}$}

Türkiye'nin kuzeybatı bölgesinde, açık göz yaralanmaları nedeni ile tedavi edilen hastaların epidemiyolojisi ve görme sonuçları değerlendirildi.

\section{GEREÇ VE YÖNTEM}

2004 ve 2008 yılları arasında Kocaeli Üniversitesi Tıp Fakültesi Göz Hastalıkları Anabilim Dalın'da açık göz yaralanması nedeni ile tedavi edilen tüm hastalar retrospektif olarak değerlendirildi.

\section{BULGULAR}

Yaşları 3 ile 79 arasında değişen, 95 hastanın 95 gözüne ait yaralanmalar değerlendirildi. Açık göz yaralanması tipi, 76 gözde (\%80), laserasyon, 19 gözde (\%20) ise yırtık idi. Sıçrayıcı cisimlerin neden olduğu göz yaralanmaları, tüm yaş gruplarında en sık görülen nedendi. Keskin cisimler 18 yaş ve üzerindeki hastalarda açık göz yaralanmalarının en az görülen nedeni iken (\%11), 18 yaştan genç hastalarda, en sık görülen nedendi $(\% 38,1)(\mathrm{p}=0,01)$. On sekiz yaşından genç hastalarda yaralanmaların \%68,3'ü evde gerçekleşirken, 18 yaş ve üzerindeki hastalarda yaralanamaların \%59,2'sinin işyerinde gerçekleştiği belirlendi $(p=0,000)$. Görme keskinliğindeki düzelmenin, izole zon 1 yaralanmalarında, diğer zon yaralanmalarına göre daha iyi olduğu görüldü $(p=0,043)$.

\section{SONUÇ}

Türkiye'nin kuzeybatısında açık göz yaralanmaları, yaş ve cinsiyete göre değişmektedir. Eğitim ve güvenlik önlemleri, açık göz yaralanmalarının önlenmesinde önemlidir.

Anahtar Sözcükler: Açık göz yaralanması; prognoz; Turkey. Kocaeli. 
Open globe injuries are an important cause of visual morbidity and blindness in the world with significant socioeconomic impact. ${ }^{[1,2]}$ Ocular trauma is an important, preventable public health problem. ${ }^{[3]}$ It has been estimated that each year 55 million eye injuries occur leading to restriction in activities of more than one day, 750,000 cases require hospitalization, and 200,000 cases are open globe injuries. ${ }^{[4]}$ From the public health and injury prevention perspective, current information on eye injury rates, identifying the cause and nature of the injuries, is needed. Different etiologies of ocular injuries are reported in different populations. In addition to cultural habits, socioeconomic status and education have a role in both the occurrence and outcomes of the injury. ${ }^{[5-9]}$

This study retrospectively analyzes the clinical characteristics, prognostic factors and visual outcome of patients with open globe injuries presenting to the Department of Ophthalmology, Kocaeli University Faculty of Medicine, Turkey. Kocaeli is located in the northwest part of Turkey, which is both an agricultural and important industrial center.

\section{MATERIALS AND METHODS}

The medical records of all cases of open globe injuries who presented to the Department of Ophthalmology, Kocaeli University Faculty of Medicine between May 2004 and December 2008 were reviewed. The research followed the tenets of the Declaration of Helsinki, and the protocol was approved by the local ethics committee. The Department of Ophthalmology of Kocaeli Medical School offers both emergency eye care and specialized care for patients of all ages with specific and complicated ocular or orbital diseases and conditions, with a 24-hour Emergency Department, which is unique in Kocaeli. Kocaeli is a province approximately $85 \mathrm{~km}$ from İstanbul, in the northwest of Turkey. The sectors that set the economy in Kocaeli can be listed as industry, trade, tourism, and agriculture. In the last 25 years, Kocaeli has retained its position as being second in Turkey in the manufacturing industry with its recorded 45,000 firms. There is a constant increase in the population. According to the 2007 census, the population was $1,437,926$.

A total of 121 eyes of 118 patients were included in the study. There were 3 bilateral penetrating injuries. Exclusion criteria were missing information $(\mathrm{n}=13)$, short follow-up ( $<4$ months) $(\mathrm{n}=11)$ and previous ocular surgery (that could affect the patients' visual prognosis) $(n=2)$. The final study sample included 95 eyes of 95 patients. None of the patients included in the study had bilateral injury. The research followed the tenets of the Declaration of Helsinki, and the protocol was approved by the local ethics committee.

The records of all patients were reviewed to de- termine patient demographics (age, sex, occupation), the involved eye, date of injury, circumstances of the injury, location of the open globe injury, mechanism (blunt, sharp and projectile) and type of the injury, presenting visual acuity (VA), therapeutic procedures (type of surgical procedure, number of surgeries), final best corrected visual acuity (BCVA) at the end of the follow-up, retinal detachment, proliferative vitreoretinopathy (PVR), sympathic ophthalmia, endophthalmitis, enucleation, and evisceration. The type of injury was classified according to the Birmingham Eye Trauma Terminology ${ }^{[10]}$ as rupture and laceration (penetrating, intraocular foreign body (IOFB), perforating). Wound location was defined according to the Ocular Trauma Classification Group ${ }^{[11]}$ For open globe injuries, Zone I injuries were confined to the cornea and limbus, Zone II involved the anterior $5 \mathrm{~mm}$ of the sclera, and Zone III injuries involved full-thickness scleral defects $>5 \mathrm{~mm}$ posterior to the limbus.

VAs were recorded with Snellen acuity charts. VA $<0.1$ was accepted as poor vision, 0.1-0.4 as moderate vision, and $\geq 0.5$ as good vision.

\section{Statistical Analysis}

Data were presented as mean \pm SD. Statistical analysis of quantitative data, including descriptive statistics, parametric and non-parametric comparisons, was performed for all variables. Frequency analysis was performed with chi-square test.

Multiple logistic analyses were performed to determine the combinations of clinical factors related to ocular trauma that predict the final outcome of VA and PVR. The multivariate model included factors found by univariate analyses to be significant predictors of final visual outcome and PVR ( $\mathrm{p} \leq 0.01$ univariate analysis). Statistical analysis was performed with the Statistical Package for the Social Sciences version 15.0 (SPSS Inc., Chicago, IL, US) software. $\mathrm{P}<0.05$ was considered statistically significant.

\section{RESULTS}

Ninety-five eyes of 95 patients with open globe injuries were included in this study. The left eye was injured in 49 patients $(51.6 \%)$ and the right eye in 46 patients $(48.4 \%)$. The mean age of the patients was $24.26 \pm 1.81$ standard mean of error (SE) years (range: 3-79 years). Seventy-two patients (75.8\%) were male and 23 were female $(24.2 \%)$. The mean age of the males was $26.02 \pm 1.72$ SE years and of the females was $17.09 \pm 2.11 \mathrm{SE}$ years. This difference was not statistically significant. Forty-one patients $(43.1 \% ; 26$ males, 15 females) were $<18$ years old and $54(56.8 \%$; 46 males, 8 females) were $\geq 18$ years old. While there was no gender difference in patients $<18$ years old, of those $\geq 18$ years, males were predominant $(p=0.017)$. 
The mean follow-up time was $10.72 \pm 9.55$ months (4-48 months). The mean time interval between trauma and presentation was 0.6 days ( 0 - 10 days). The majority of cases ( 71 cases, $74.7 \%$ ) presented to the hospital within 24 hours of their trauma. Twenty-one patients $(22.1 \%)$ presented after a delay of $>24$ hours, and 3 patients $(3.2 \%)$ after a delay of more than one week. All patients were operated within 12 hours of their presentation to the hospital, as soon as they were appropriate for general anesthesia. Forty-four eyes $(46.3 \%)$ were repaired with one operation, 31 eyes $(32.6 \%)$ required two operations, and 20 eyes $(21.1 \%)$ required 3 or more procedures. The mean number of surgeries was 1.85 .

The majority of open globe injuries occurred in June, July, August, September, and October. The distribution of injuries by month is shown in Fig. 1. Most patients $(42.1 \%)$ were workers. Housewives represent a portion of the Turkish population and represented about $5.3 \%$ of the population in the current study. 'No occupation' included those who were not working or were retired $(8.4 \%)$ The number and percentage of patients in each occupation are presented in Table 1. In 76 eyes $(80 \%)$, the type of open eye injury was laceration [in 54 eyes $(56.8 \%)$ penetrating, 5 eyes $(5.26 \%)$ perforating, 17 eyes (17.8\%) IOFBs] and in 19 eyes $(20 \%)$, the injury type was rupture. In all age groups, projectile objects were the most common cause of injury (Fig. 2). The mechanism of injury was different between age groups, and this difference was statistically significant. In patients $\geq 18$ years old, sharp objects $(11.1 \%)$ were the least prevalent cause of

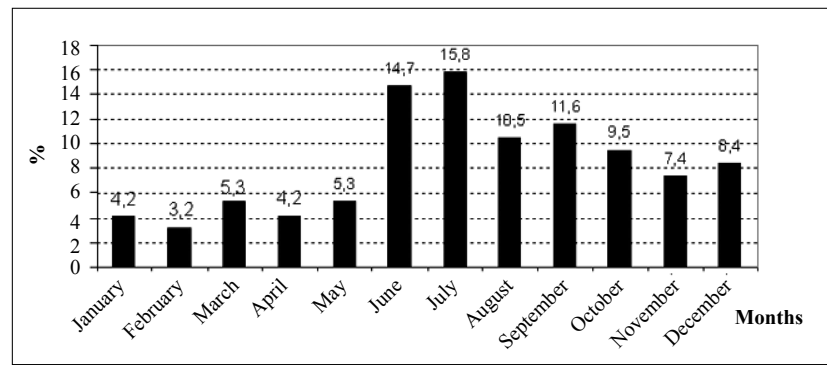

Fig. 1. Distribution of patients admitted according to months.

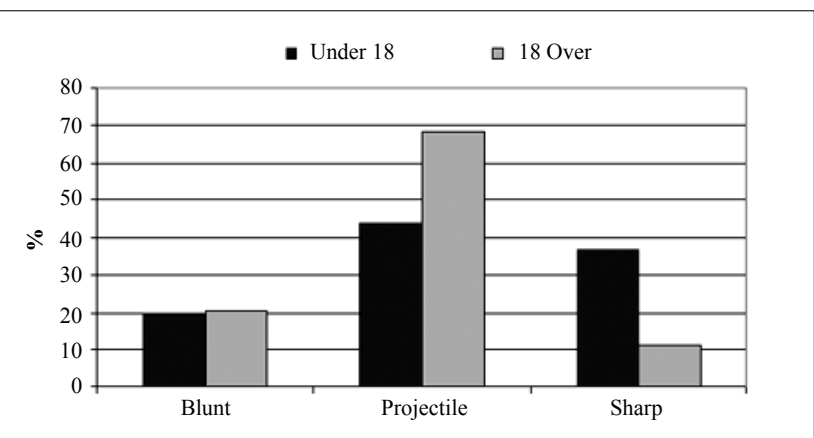

Fig. 2. Frequency distribution of trauma agents according to age groups.
Table 1. The number and percentage of patients according to their occupation

\begin{tabular}{lcc}
\hline Occupation & Frequency & Percentage (\%) \\
\hline Workers & 40 & 42.1 \\
Students & 21 & 22.1 \\
Preschool children & 21 & 22.1 \\
Housewives & 5 & 5.3 \\
No occupation & 8 & 8.4 \\
Total & 95 & 100 \\
\hline
\end{tabular}

open globe injuries; however, traumas with sharp objects were common in patients $<18$ years old $(38.1 \%)$ $(\mathrm{p}=0.01)$ (Fig. 3). Knife was the most prevalent cause $(57.1 \%)$ in all traumas with sharp instruments. Glass was the most prevalent cause $(41.8 \%)$ in all traumas with projectile materials (Fig. 4).

In this study, ocular trauma occurred mainly at home $(38.9 \%)$ or the workplace $(33.7 \%)$, followed by outdoor activities-related (20\%) and traffic accidentrelated $(7.4 \%)$ traumas (Fig. 5). In patients $<18$ years old, most injuries occurred at home $(68.3 \%)$, while in patients $\geq 18$ years old, the majority of ocular traumas occurred at work $(59.2 \%)(\mathrm{p}=0.000)$.

Regarding classification according to zone, $52.2 \%$ of all traumas occurred in Zone I, 5.3\% in Zone II and $9.5 \%$ in Zone III. In $16.8 \%$, the site of ocular trauma included Zones I and II; in 7.4\% Zones I and III; and in $8.4 \%$ Zones I, II and III. There was no significant difference between age groups according to the zone of the injury.

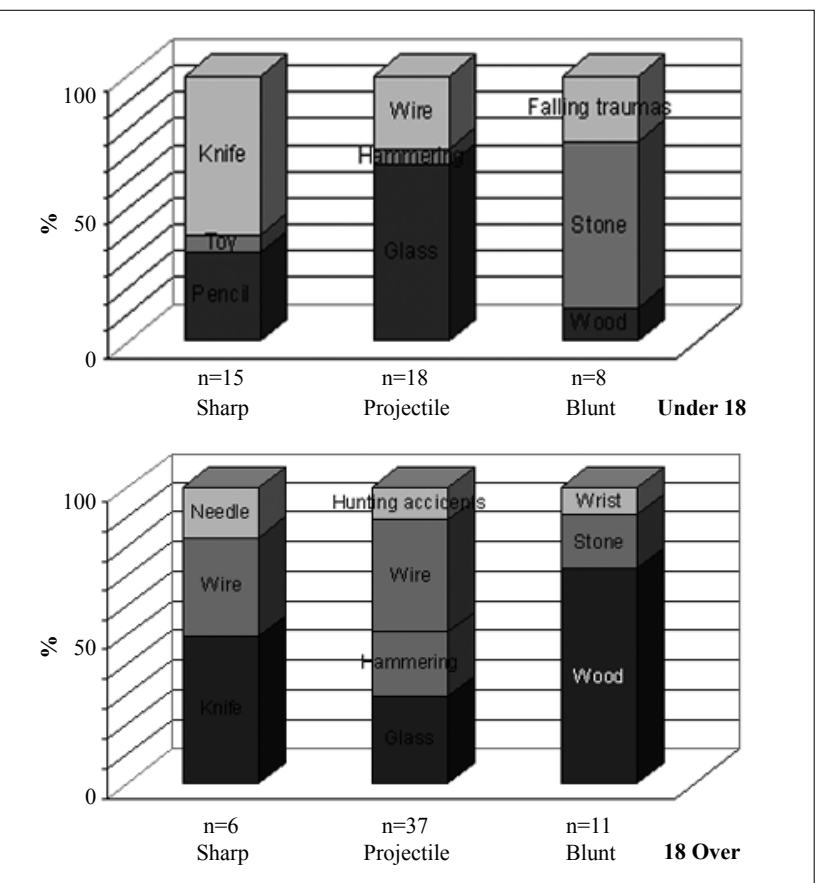

Fig. 3. Frequency distribution of trauma etiology according to age groups. 


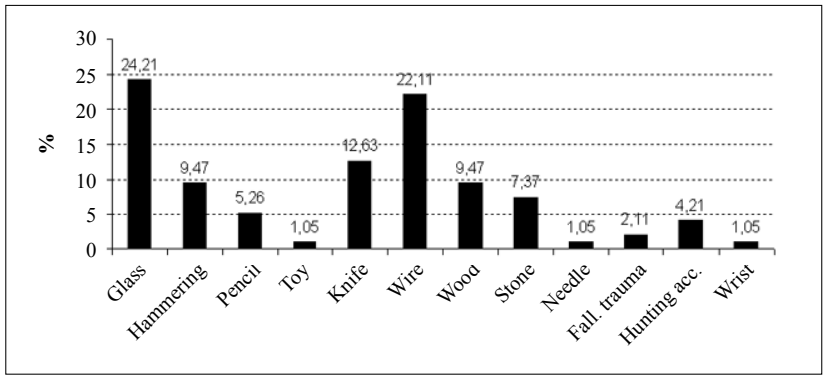

Fig. 4. Trauma etiology in the entire study group.

An IOFB was observed in 17 eyes (17.9\%); 7 in the anterior segment and 10 in the posterior segment. Thirteen were metal, 2 were wood and 2 were glass. Twelve eyes (12.6\%) developed retinal detachment during the follow-up and 8 of them were IOFB injuries. Seven of the 12 eyes that developed a retinal detachment had undergone scleral buckling surgery and 5 had not. In 5 eyes, globes were perforated with foreign bodies settled in the orbit. All IOFBs were glass. Three of the 5 perforated eyes developed retinal detachment that required pars plana vitrectomy, and final moderate BCVA was attained. None of the perforating injuries developed endophthalmitis.

Three cases had post-traumatic endophthalmitis. Two of these 3 eyes had IOFB, and endophthalmitis developed on the 4th postoperative day after primary repair done on the day of injury. Final moderate BCVA was attained after vitrectomy and IOFB removal. One eye with endophthalmitis without IOFB, of a patient who admitted to the hospital on the second day of injury, rapidly deteriorated and required an evisceration. One patient required an enucleation during the primary surgery because of extensive ocular damage, and one eye required an evisceration because of phthisis bulbi.

Only $9.5 \%$ of the patients had presenting VA of $\geq 0.5$. A total of $35.8 \%$ of our patients had final BCVA of $\geq 0.5$ and $33.7 \%$ had a final BCVA $<0.1$. The final BCVA compared with the presenting VA is shown in Table 2. Eight patients (8.4\%) who had good initial VA level also had good final BCVA. Forty-three patients $(45.2 \%)$ had regression or no improvement, and 52 patients $(54.7 \%)$ showed improvement in the BCVA level. Isolated Zone I lesions showed more improvement in the BCVA than observed with injuries in other zones $(p=0.043)$.

For final VA, the following variables were included in the logistic regression model: zone of injury, presenting VA, presentation time to hospital, and IOFB. None of these variables was shown to be a significant independent predictor of final VA.

For PVR, zone of injury, presenting VA, number of surgeries, and IOFB were included in the logistic re-

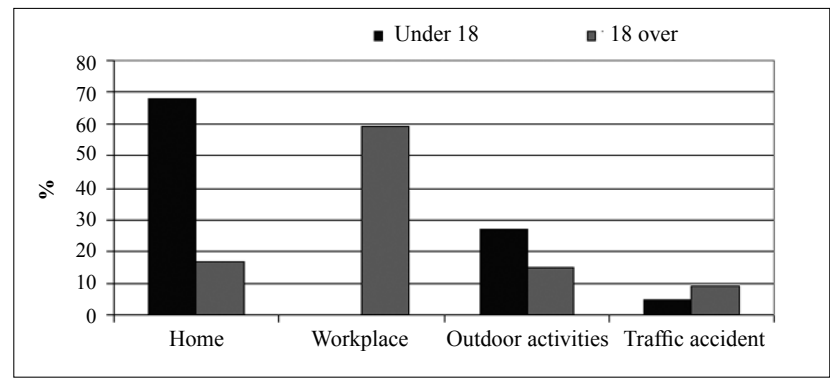

Fig. 5. Frequency distribution of site of trauma occurrence according to age groups.

gression model. Multivariate logistic regression analysis demonstrated that the number of surgeries (odds ratio [OR], 1.89; 95\% confidence interval [CI], 1.1-3.1; $\mathrm{p}=0.015)$ and IOFB were the significant predictors of final PVR (OR, 4.36; 95\% CI, 1.2-15.6; $\mathrm{p}=0.024)$.

\section{DISCUSSION}

Although ocular trauma is a worldwide cause of preventable monocular blindness, there have been few population-based studies on the epidemiology, prevalence and risk factors. ${ }^{[3,12]}$ Recently, studies in Asia, the Middle East and Europe are emerging. ${ }^{[6-9]}$ The hospital records of patients with open globe injury have been used as a source of information and provide important insights into the epidemiology of open globe injury in the Turkish population.

In our study, men were affected more than women, and constituted $75.8 \%$ of patients with a 3.12 male: female ratio. The reported incidence and prevalence ratios between men and women range from 2 to 5..$^{[3,6,9,13,14]}$ A male predominance is universally reported and thought to be related to occupational exposure, participation in dangerous sports and hobbies, alcohol usage, and risk-taking behavior. The mean age of our patients was 24.26 \pm 1.81 SE years (range: 3-79 years), which was younger than in most previous reports ${ }^{[15-18]}$ but similar to reports from Egypt, Iran and the southern part of Turkey. ${ }^{[6-8,19]}$ The majority of workers were male, which may explain the lower mean age in the female group.

In this study, most open globe injuries occurred in June, July, August, September, and October. In the other Turkish study done in the southern part of Tur-

Table 2. Initial VA versus final BCVA

\begin{tabular}{lcccc}
\hline Initial VA & \multicolumn{4}{c}{ Final BCVA } \\
\cline { 2 - 5 } & 0.5 to 1.0 & 0.1 to 0.49 & $<0.1$ & Total \\
\hline 0.5 to 1.0 & 8 & 1 & 0 & 9 \\
0.1 to 0.49 & 5 & 2 & 2 & 9 \\
$<0.1$ & 21 & 26 & 30 & 77 \\
Total & 34 & 29 & 32 & 95 \\
\hline
\end{tabular}

VA: Visual acuity; BCVA: Best corrected visual acuity. 
key, most injuries occurred in July and August. ${ }^{[20]}$ In another study, from Iran, the most common months of admission were June, August, September, and March. ${ }^{[7]}$ In a study from Ireland, August was the common month of admission. ${ }^{[21]}$ Eye injuries most commonly occur during summer in the northern hemisphere when schools are closed in most countries and when outdoor activities increase in warmer weather. The higher incidence of trauma in October is different from other studies but similar to the report of Gyasi et al. ${ }^{[19]}$

About $25.3 \%$ of patients presented after a delay of more than 24 hours, slightly higher that the $18 \%$ reported by Soliman et al. ${ }^{[6]}$ from Egypt. Only 3.2\% of patients presented after a delay of more than one week. Soylu et al. ${ }^{[8]}$ reported patients with delayed presentation of 1 to 60 days in the southern part of Turkey. The cause of more delay in the south of Turkey may be due to the expansive rural areas in that region compared to the north.

In the present study, $38.9 \%$ of ocular trauma occurred at home. This proportion was higher when compared with other studies $(14.1-28.9 \%){ }^{[6,7,20,22]}$ The majority of the pediatric injuries $(68.3 \%)$ occurred at home. In most studies, ocular injuries are reported to occur most frequently at work. A total of $33.7 \%$ of all traumas occurred in the workplace in our study, similar to the report of Byhr et al. ${ }^{[23]}$ but higher than other reports $(23-26 \%) .{ }^{[6,7]}$

When we compare trauma etiologic factors in our study population to those from other studies, trauma with glass was found to be higher $(24.21 \%$ vs. 3.7$13.7 \%),{ }^{[7,20,24]}$ while that due to knives was comparable $(12.6 \%$ vs. $1.9-11.4 \%) .^{[7,24]}$ In patients $\geq 18$ years old, projectile traumas were the main open globe injury type, and generally were occupational traumas. The main causes were glass and while cutting wire, or while hammering, in which a small piece of material separated to penetrate the globe at excessive speed. IOFBs were also common, occurring in $17.9 \%$ of eye injuries, comparable with other studies $\left(16.8 \%{ }^{[9]}\right.$ $\left.-20.1 \%{ }^{[8]}\right)$. In patients $<18$ years old, sharp and projectile traumas were the main open globe injury type and generally occurred at home. Sharp trauma with knife and projectile traumas with a small piece of glass separated especially from falling glass were the main causes in patients $<18$ years old. Most of the eye traumas in this study were agent-related and resulted from the use or misuse of an object ordinarily considered unsafe for an unsupervised child. Thompson et al. ${ }^{[25]}$ reported that most injuries in the pediatric population took place at home. This means that most of the injuries at home were preventable.

The distribution of trauma localization was comparable to that in other studies with small differences.
$52 \%$ of all traumas occurred in Zone I. In a study involving a Korean population, $45.8 \%$ of traumas were in Zone $\mathrm{I}^{[18]}$ In other studies by Thakker and Ray $(48.8 \%)^{[26]}$ and by Mansouri $(56 \%){ }^{[7]}$ similar results were noted. Isolated Zone I injuries showed more improvement in VA than other zones. Both the extension of trauma and localization of trauma are limited in isolated Zone I injuries. PVR was noted in $16.3 \%$ of traumas in isolated Zone I, whereas $40.6 \%$ of traumas extending to the sclera developed PVR. The Cleary and Ryan model demonstrated that the necessary factors for the initiation of intraocular proliferation that inevitably leads to retinal detachment were a full-thickness scleral wound and blood-vitreous admixture. ${ }^{[27]}$ PVR occurrence was significantly higher in traumas that required two or more surgical interventions. Retinal or vitreous involvements in injury cause proliferation and increase in the number of surgeries.

Public health promotion activities in Turkey should focus on minimization of ocular traumas as an important public health problem. Use of protective eyeglasses at work must be encouraged. The young mean age, with $43.2 \%$ of patients under 18 years, points to the importance of public education and improvement in the safety culture. Since the most effective education of the public is through the media, it is recommended to devote additional effort on dissemination of information on ocular injuries and the existing dangers. Lectures about preventive measures may be added to the educational plans beginning from preschool classes.

\section{REFERENCES}

1. Négrel AD, Thylefors B. The global impact of eye injuries. Ophthalmic Epidemiol 1998;5:143-69.

2. Thylefors B. Epidemiological patterns of ocular trauma. Aust N Z J Ophthalmol 1992;20:95-8.

3. Whitcher JP, Srinivasan M, Upadhyay MP. Corneal blindness: a global perspective. Bull World Health Organ 2001;79:21421 .

4. Wong TY, Tielsh JM. Epidemiology of ocular trauma. In: Tasman W, Jaeger EA, editors. Duane's clinical ophthalmology. Lippincott Williams and Wilkins; 1999. p. 1-13.

5. Strahlman E, Elman M, Daub E, Baker S. Causes ofpediatric eye injuries. A population based study. Ach Ophthalmol 1990;108:603-6.

6. Soliman MM, Macky TA. Pattern of ocular trauma in Egypt. Graefes Arch Clin Exp Ophthalmol 2008;246:205-12.

7. Mansouri M, Faghihi H, Hajizadeh F, Rasoulinejad SA, Rajabi MT, Tabatabaey A, et al. Epidemiology of open-globe injuries in Iran: analysis of 2,340 cases in 5 years (report no. 1). Retina 2009;29:1141-9.

8. Soylu M, Sizmaz S, Cayli S. Eye injury (ocular trauma) in southern Turkey: epidemiology, ocular survival, and visual outcome. Int Ophthalmol 2010;30:143-8.

9. Cillino S, Casuccio A, Di Pace F, Pillitteri F, Cillino G. A five-year retrospective study of the epidemiological characteristics and visual outcomes of patients hospitalized for ocular trauma in a Mediterranean area. BMC Ophthalmol 2008;8:6. 
10. Kuhn F, Morris R, Witherspoon CD, Heimann K, Jeffers JB, Treister G. A standardized classification of ocular trauma. Ophthalmology 1996;103:240-3.

11. Pieramici DJ, Sternberg P Jr, Aaberg TM Sr, Bridges WZ Jr, Capone A Jr, Cardillo JA, et al. A system for classifying mechanical injuries of the eye (globe). The Ocular Trauma Classification Group. Am J Ophthalmol 1997;123:820-31.

12. Tielsch JM. Frequency and consequences of ocular trauma: a population perspective. Ophthalmol Clinics North Am 1995;8:559-67.

13. Tielsch JM, Parver L, Shankar B. Time trends in the incidence of hospitalized ocular trauma. Arch Ophthalmol 1989;107:519-23.

14. Karlson TA, Klein BE. The incidence of acute hospital-treated eye injuries. Arch Ophthalmol 1986;104:1473-6.

15. Wong TY, Tielsch JM. A population-based study on the incidence of severe ocular trauma in Singapore. Am J Ophthalmol 1999; 128:345-51.

16. Rofail M, Lee GA, O'Rourke P. Prognostic indicators for open globe injury. Clin Experiment Ophthalmol 2006;34:783-6.

17. McCarty CA, Fu CL, Taylor HR. Epidemiology of ocular trauma in Australia. Ophthalmology 1999;106:1847-52.

18. Kim JH, Yang SJ, Kim DS, Kim JG, Yoon YH. Fourteen-year review of open globe injuries in an urban Korean population. J Trauma 2007;62:746-9.
19. Gyasi M, Amoaku W, Adjuik M. Epidemiology of hospitalized ocular injuries in the upper East region of ghana. Ghana Med J 2007;41:171-5.

20. Cakmak SS, Unlu MK, Olmez G, Caca I, Sakalar YB, Acemoglu H. Penetrating eye injuries from southeasthern Anatolia region of Turkey. Public Health 2004;118:570-4.

21. Canavan YM, O'Flaherty MJ, Archer DB, Elwood JH. A 10year survey of eye injuries in Northern Ireland, 1967-76. Br J Ophthalmol 1980;64:618-25.

22. Parver LM, Dannenberg AL, Blacklow B, Fowler CJ, Brechner RJ, Tielsch JM. Characteristics and causes of penetrating eye injuries reported to the National Eye Trauma System Registry, 1985-91. Public Health Rep 1993;108:625-32.

23. Byhr E. Perforating eye injuries in a western part of Sweden. Acta Ophthalmol (Copenh) 1994;72:91-7.

24. Smith D, Wrenn K, Stack LB. The epidemiology and diagnosis of penetrating eye injuries. Acad Emerg Med 2002;9:209-13.

25. Thompson CG, Kumar N, Billson FA, Martin F. The aetiology of perforating ocular injuries in children. Br J Ophthalmol 2002;86:920-2.

26. Thakker MM, Ray S. Vision-limiting complications in openglobe injuries. Can J Ophthalmol 2006;41:86-92.

27. Cleary PE, Ryan SJ. Method of production and natural history of experimental posterior penetrating eye injury in the rhesus monkey. Am J Ophthalmol 1979;88:212-20. 